\title{
Tax Stimulation of Innovation Activities Enterprises
}

\author{
Andrey Nechaev \\ Professor, Department of Management of Industrial Enterprises, Irkutsk State Technical University, \\ Irkutsk, Russian Federation \\ Email: n-a-s@mail.ru \\ Oksana Antipina
}

Associate professor, Department of Economic Theory and Finance, Irkutsk State Technical University, Irkutsk, Russian Federation, 664049 Russian Federation, Irkutsk, Bagration st, 54/8 - 28

Email: antipina_oksana@mail.ru

\section{Doi:10.5901/mjss.2015.v6n1s2p42}

\section{Abstract}

Purpose: Russia's transition to innovation economy is one of the main ways to restore and develop the economic potential of the country. To achieve these objectives, it is necessary to ensure corresponding conditions and environment for the effective functioning of all economic entities. That concerns, first of all, tax incentives for innovative activities of enterprises. Methods: The study used a technique for comparative analysis. Results: In this regard, the article offers a scheme demonstrating the impact of the tax component, at every stage of the innovation life cycle, on the operating rate of enterprises as well as innovative development of the country. The system allows changing the rate of tax burden on economic entities by means of applying tax rate adjustment factors for the identified types of taxes, levies, duties and expenses with regard to expenditure pattern and export and import operations of current and permanent assets. Conclusions: basing on the analysis conducted, interdependencies between the fluctuations in interest rates on securities, income tax rate, capital tax (including the progressive, regressive and proportional taxation) and the rate of income on securities and revenue (before tax and retained profits) have been identified, which appear in the course of relations between state revenue (fiscal control) bodies, innovationactive economic entities and investors.

Keywords: innovation activities of enterprises, tax incentives, innovation life cycle, tax exemptions, business entities

\section{Introduction}

Currently, the issue of economic transition to innovative development is becoming even more important and relevant. The state's role in terms of innovation projects support is to develop and fulfill programs on innovative activities stimulation; to use fiscal and other elements of state regulation that ensure the efficiency and determine the need for innovative solutions of individual enterprises; to organize effective interaction between applied science and industrial corporations.

The peculiarities of innovative development of areas, the necessity and importance of business units' carrying out innovative activities are specified and studied in the works by J.Shumpeter (Shumpeter, 1982), N.Kondratyev (Kondratyev, 1984 ), S.Kuznets (Kuznets, 1955), P.Drucker (Drucker, 1985, 2013), M.Porter (Porter, 1985), F.Nechaev (Nechaev, 2012), Y.Yakovets (Yakovets, 1999), S.Glazyev (Glazyev, 1993).

The need for tax incentives for innovative activities of economic entities is analyzed in the works by Y.Ananiashvili (Ananiashvili, 2010), A.Laffer (Laffer et al., 2008), N.Ivanova (Ivanova, 2009), S.Uvarova (Uvarova, 2011).

\subsection{The taxation system in the innovation economy}

First of all, it is necessary to define what tax system of innovation economy consists of. The tax system of innovation economy is represented by a combination of interrelated elements (subjects, objects of taxation, tax rates, tax incentives and privileges, due dates for tax payment), based on certain principles (such as: the principles of commitment, fairness, certainty, efficiency, unity, stability, flexibility, optimality, proportionality), the purpose of which is to help establish and collect taxes, define taxation forms and methods to provide for the special type of economy based on innovations, technological improvements, manufacture and export of high-tech products to ensure economic growth and competitive edge of a country. 


\subsection{Tax optimization of innovative products and services}

To increase the level of innovative economic development, tax optimization for innovative products and services is required. In this case, tax optimization for innovative products and services is represented by a scheme of values of economic indicators, optimum values that would be associated with the best systems of tax establishment and collection in the country, rate determination, payment order with regard to products and services which meet the priority tasks of science and are characterized by scientific and technological novelty, high technologies and economic effects from their realization and are supported by scientific evidence.

\subsection{The life cycle of innovation}

It should be noted that specific tax planning tools should be used at each stage of the innovation life cycle. Here, the innovation life cycle implies a combination of processes comprising the main phases from the innovation development and till the final stage of its exploitation, with each stage allowing to evaluate the effectiveness of research conducted and determine the main reinvestment areas which will contribute to profit maximization of economic entities and businesses, by means of defining the correlation and interdependencies between costs on studies for a fixed period of time and the assessment of their efficiency, as well as between the amount of proceeds and fluctuations in demand for innovative products.

\section{Methods}

Innovative development of a country largely depends on the efficient activity of innovation-active economic entities, which is contingent on a variety of factors, with the established tax burden on enterprises one of them. The analysis carried out showed that in Russia the tax burden rate for enterprises is much lower as comparing to majority of developed countries with high rates of innovation development.

The relevance of tax incentives for innovation processes is actively studied in the works by N.Ivanova (Ivanova, 2009). She notes, in particular, that special tax planning tools, the effectiveness of which is evaluated by using a variety of methods, should be applied for every type of activity. 2010).

The assessment of tax burden on business entities is also made in the works by Y.Ananiashvili (Ananiashvili,

Works by A.Laffer that study the patterns of tax rate influence on the amount of tax revenues (Laffer et al., 2008) are also popular.

\section{Results}

3.1 The relationship between the amount of income of innovation-active economic entities on the values of the interest rates on securities

The analysis carried out revealed that the increase in income upon securities issued by innovation-active economic entities largely depends on the change of interest rates (Figure 1).

The scope of financing of innovation activity of economic entities at any stage of their life cycle is much dependent on the interest rates on securities issued by them. Higher interest rates lead to considerable increase of investment into innovation activity and increase in demand for debt securities (demand arc $S$ in Figure 1). 


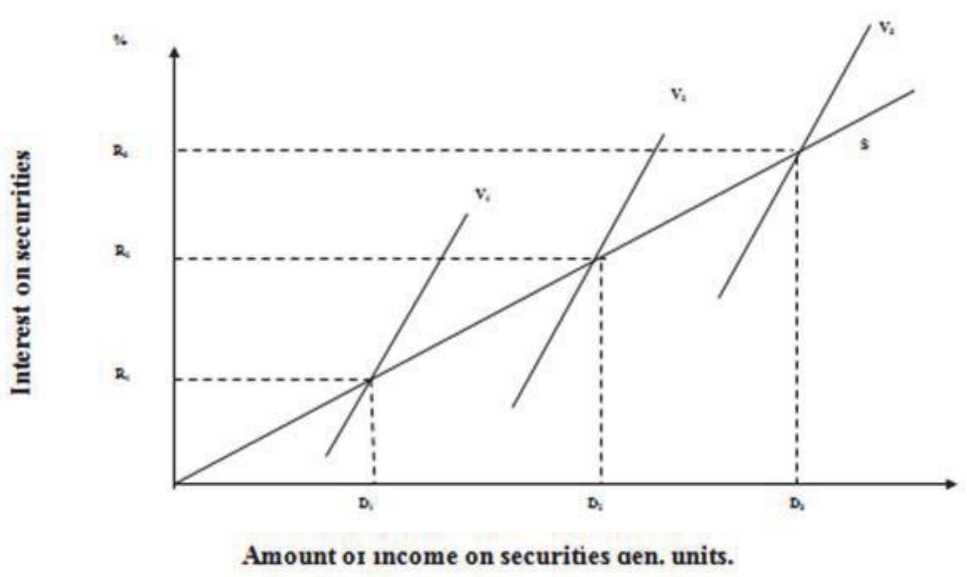

Fig. 1. The relationship between the amount of income of innovation-active economic entities on the values of the interest rates on the securities issued by them

Where: D1, D2, D3 - the amount of income on securities; R1, R2, R3 - the interest rate of the Central Bank; V1, V2, V3 the amount of the securities market; $\mathrm{S}$ - the demand for CB.

Dependence shown in Fig. 1 shows an increase in demand for securities (see Fig. 2), which is due to an increase in investment in securities, the rates for which is directly proportional to the size of the amount of investment that will argue about the increasing amount of income on securities of innovation-active businesses.

\subsection{The relationship between changes of interest rates of tax on capital and the amount of investment}

The analysis carried out revealed a direct dependence of the volume of investments into innovation activities on the change of the interest rate of capital tax levied on the realized capital gain derived from the sales of securities and / or by way of dividends. Maximum tax rates result in considerable investment reduction. The decrease in tax rates contributes to more favourable conditions for investment into innovative development of economic entities (Figure 2)

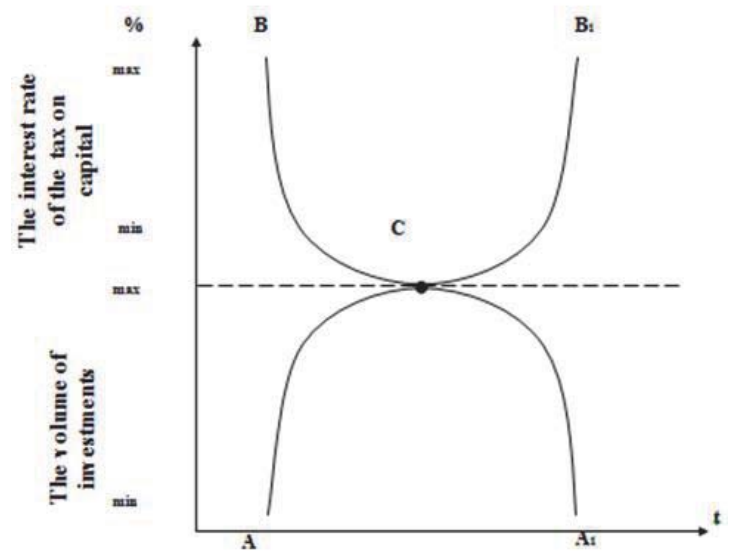

Fig. 2. The relationship between changes of interest rates of tax on capital and the amount of investment or innovation activities of business entities for a period of time

Where: AA1 - the change in volume of investments; BB1 - changes in interest rates; C - the most appropriate area of taxation for investors.

Dependence shown in Fig. 2 shows that the increase in investment should be inversely proportional to the rate of tax on capital, as it will attract additional financial resources to a greater extent in the activities of innovation-active businesses. 


\subsection{The relationship between the amount of income on securities and tax systems}

Moreover, the income of innovation-active economic entities can be significantly reduced by the introduction of progressive taxation for capital tax (Figure 3). By the introduction of progressive taxation for capital tax for innovationactive economic entities, a significant decrease in their income, gained including through the sales of securities issued, is observed, which, eventually, leads to a shortage of investment resources to carry out innovation activity as well as innovative development recession on the whole.

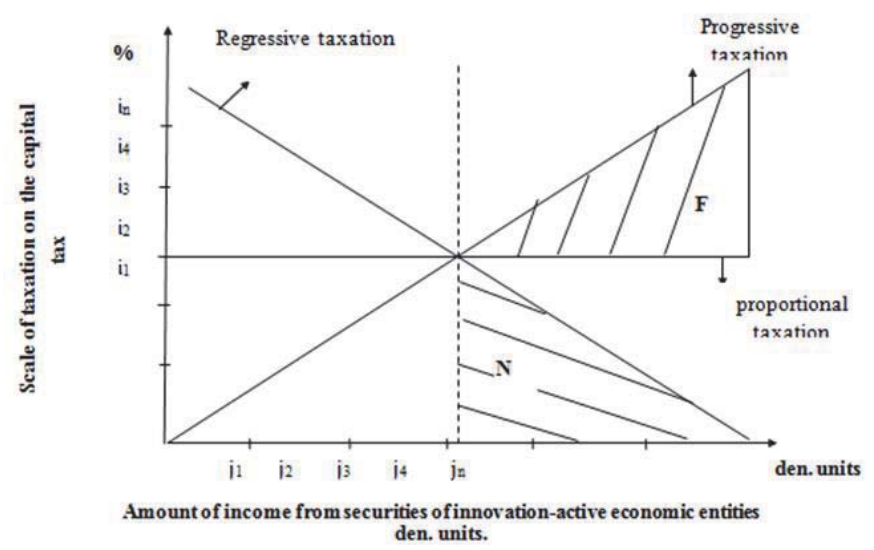

Fig. 3. The relationship between the amount of income on securities and tax systems (proportional, progressive, regressive)

Where: $\mathrm{F}$ - the area of taxation the most acceptable to the fiscal authorities; $\mathrm{N}$ - the area of taxation the most appropriate for the activities of innovation-active businesses; i1, i2 ... in - the value of interest rates on the capital tax; j1, j2 ... jn - the value of income on securities of innovation-active businesses.

Fig. 3 shows the most appropriate area of taxation for the fiscal authorities (area F), which provides the largest amount of cash flows in the form of tax revenues.

In turn, the area of taxation $\mathrm{N}$ is the most appropriate for the activity of innovation-active business entities, which ensure the flow of investment, contributing to an increase in income of companies which, in the case of the reduced tax rate on capital will attract the largest number of investors to finance innovation businesses.

\subsection{The relationship between the amount of pre-tax profit and tax systems}

The amount of income tax depends on the income tax rate, with the latter directly related to the amount of the taxable profit of innovation-active economic entities. Hence, in view of the aforesaid, there is a need to determine the most appropriate tax area, taking into account the interests of state revenue bodies, innovation-active economic entities and investors (Figure 4).

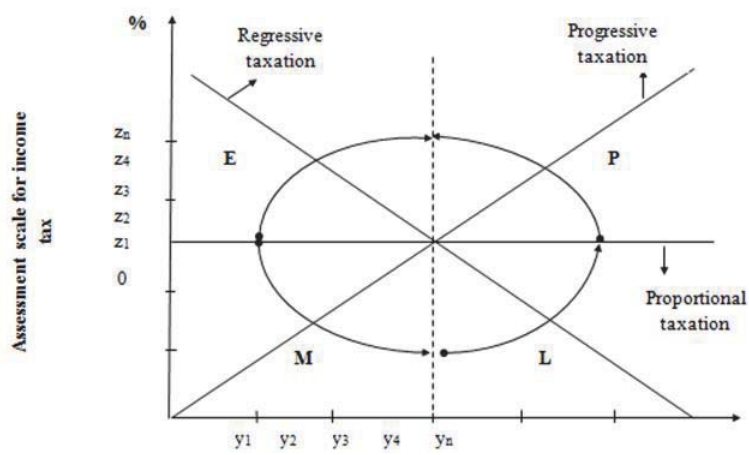

Fig. 4. The relationship between the amount of pre-tax profit and tax systems (proportional, progressive, regressive) 
Where: $E, L$ - Region of interest rate increase with increasing amounts of profit of innovation-active businesses; $P$ - region of interest rate increases with a decrease in the volume of profits of innovation-active businesses; $M$ - the area to reduce the interest rate by increasing the volume of profits of innovation-active businesses; ; z1, z2 ... zn - value of interest rate of income tax; y1, y2 ... yn - the value of profit before taxation of innovation-active businesses.

Fig. 4 presents the most appropriate area for investors (Region M), for the fiscal authorities (area E, L) and the region $\mathrm{P}$ - the most unfavorable for the fiscal authorities, and for the work of innovation-active businesses.

Finding the organization in the field of taxation $\mathrm{M}$ will promote innovation and the active pursuit of an economic entity to reduce the cost of goods (works, services) in order to increase taxable profit will be taxed at the income tax rate is inversely proportional to its size. In turn, the increased size of the taxable profit for taxation at the lower rate of income tax will save the amount of tax revenue at an acceptable level of fiscal authorities. Furthermore, it will lead to the fact that the larger size of retained earnings will be subject to lower interest rates of tax on capital (area N Fig. 3). This, in turn, will lead to an increase in tax revenues in the part of the tax on capital.

The identified interdependencies, shown in Figure 1, 2, 3, 4, allow us to determine the optimal taxation area for income tax, capital tax in the process of cooperation between state revenue bodies, investors and innovation-active economic entities for the purpose of implementation of various investment projects (industrial, scientific and technical, commercial, financial, and socio-economic).

\section{Discussion}

Note that the present system is based on the application of corresponding adjusting factors, the purpose of which is to reduce the tax burden depending on performance results of innovation-active economic entities.

There is no consensus on the methods for calculating tax burden in economic literature. Some researchers suggest omitting individual income tax in the calculation of tax burden for organizations, as in this case organizations act as fiscal agents (Atkinson \& Ezell, 2012).

According to another conclusion, it has not been defined yet what kind of taxes and fees (indirect taxes) should be included into the calculation of tax burden for organizations (Dynkin, 2005).

Finally, there are discussions about an indicator that is to be associated with the absolute tax burden - experts have failed to fix it until today. Currently, net and gross proceeds, added value and new value are being considered to represent such an indicator (Golichenko, 2006).

\section{Conclusion}

The relevance of the use of various tax planning tools to stimulate innovation activity of enterprises is beyond any doubts. At the same time, the present interpretations of such terms as "innovative economy tax system", "taxation optimization for innovative products and services", and "innovation life cycle" reveal the necessity for effective enforcement of tax instruments, in fact: tax rate adjustment, tax incentives application, the use of special tax regimes in order to secure economic conditions to ensure a balanced development of innovation-driven economy.

The innovation activity stimulation system presented allows enhancing the efficiency of innovation-active economic entities by applying tax rate adjustment factors depending on their performance in order to reduce the tax burden on enterprises at all phases of the innovation life cycle.

Besides, the identified relations between state revenue bodies, investors and innovation-active economic entities allow determining the optimum taxation area for profit tax, capital tax, which ensures the growing tax component with regard to such taxes, by increasing tax bases (undistributed, retained profits and pretax profit) of organizations.

\section{References}

Ananiashvili, Y. (2010). Taxes and macroeconomic equilibrium: the Laffer-Keinsian synthesis. Stockholm: SF \& CC Press. Atkinson, R. \& S. Ezell, 2012. Innovation Economics: The Race for Global Advantage. Yale University Press, pp: 440.

Drucker, P.F., 1985. Innovation and Entrepreneurship. New York: Harper \& Row.

Drucker, P.F., 2013. On Innovation. Boston: Harvard Business School Publishing Corporation, pp: 176.

Dynkin, A., (2005). Innovative priorities of the state. Moscow: Science.

Glazyev, S. (1993). The theory of long-term technical and economic development. Moscow: VLADAR.

Golichenko, O. (2006). The National Innovation System of Russia: state and development. Moscow: Nauka.

Ivanova, N. (2009). Tax stimulation of innovative processes. Moscow: Russian Academy of Sciences.

Kondratiev, N.D., 1984. The Long Wave Cycle. New York: Richardson \& Snyder. 
Kuznets, S., 1955. Economic Growth and Income Inequality. American Economic Review, 45: 1-28.

Laffer, A., Moore, S., \& Tanous, P. (2008). The End of Prosperity: How Higher Taxes will Doom the Economy - if We Let it Happen. New York: Threshold Editions .

Nechaev, A.S., 2012. Efficiency of investments attraction into organization of production processes at industrial enterprises. Bulletin of Irkutsk state technical university, 3: 237-241.

Porter, M.E., 1985. Competitive Advantage. New York: Free Press.

Shumpeter, J., 1961. The Theory of Economic Development. New York: Oxford University Press.

Uvarova, S. 2011. Formation of a system of tax incentives for innovation processes in the Russian economy. Finance and Credit, 35 (467), 19-25.

Yakovets, Y., 1999. Cycles. Crises. Forecasts. Moscow: Nauka, pp: 448. 